\title{
Petrologic, Elemental and Isotopic Characterization of Unique Depleted Olivine Microwebsteritic Shergottite Northwest Africa 13179
}

A. J. IRVING ${ }^{1}$, P. K. CARPENTER ${ }^{2}$, M. RighteR ${ }^{3}$, T. J. LAPEN $^{3}$, J. H. TEPPER ${ }^{4}$ AND B. HOEFNAGELS

${ }^{1}$ Dept. of Earth \& Space Sciences, University of Washington, Seattle, irvingaj@uw.edu; ${ }^{2}$ Dept. of Earth \& Planet. Sci., Washington Univ., St. Louis; ${ }^{3}$ Dept. of Earth \& Atmos.

Sci., Univ. of Houston; ${ }^{4}$ Dept. of Geology, UPS, Tacoma.

A 175 gram crusted stone found in the Sahara is the first known example of an ultramafic Martian meteorite with depleted ITE characteristics. The specimen is a mediumgrained $(\sim 0.7 \mathrm{~mm})$ aphyric pyroxenite composed mainly of zoned pyroxenes, $\sim 15$ vol. $\%$ olivine and $<5$ vol. $\%$ interstitial maskelynite, plus accessory chromite, Ti-chromite, pyrrhotite, pentlandite, ilmenite, silica polymorph and merrillite. Pyroxene grains are zoned from orthopyroxene cores ( $\mathrm{Fs}_{14.7}$ $\left.{ }_{14.9} \mathrm{Wo1} 1.2-1.4, \mathrm{FeO} / \mathrm{MnO}=28-30\right)$ to pigeonite $(\mathrm{Fs} 20.5-44.2 \mathrm{Wo4} .0-$ 12.6, $\mathrm{FeO} / \mathrm{MnO}=27-36)$ and subcalcic augite $\left(\mathrm{Fs}_{34.9} \mathrm{Wo}_{28.4}\right.$, $\mathrm{FeO} / \mathrm{MnO}=35$ ). Olivine grains are zoned from $\mathrm{Fa}_{17.7}$ cores to $\mathrm{Fa}_{21.6-30.3} \operatorname{rims}(\mathrm{FeO} / \mathrm{MnO}=44-50)$.

The bulk rock $\mathrm{CaO}$ (4.7 wt.\%), $\mathrm{Al}_{2} \mathrm{O}_{3}$ (3.8 wt.\%) and $\mathrm{Mg} /(\mathrm{Mg}+\mathrm{Fe})$ value $(0.75)$ place this specimen in the ultramafic field of [1], and the REE pattern shows strong depletions in La$\mathrm{Sm}$. The $\varepsilon H f$ value of +55.3 confirms an affinity to depleted shergottites like Tissint and at least 15 other presumed launchpaired Martian stones [2]. We interpret NWA 13179 to be the first known igneous cumulate from a (possibly quite ancient) depleted shergottite magma.

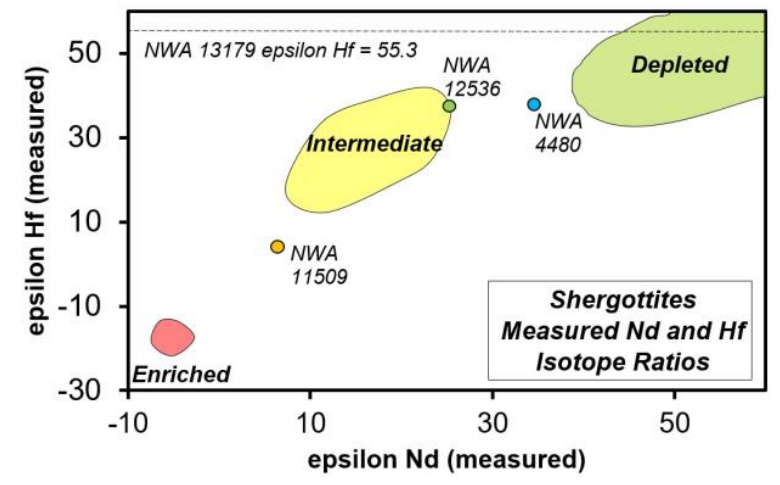

References: [1] Irving A. et al. (2010) LPS LXI, \#1547

[2] Lapen T. et al. (2017) Science Advances 3, e1600922. 